\title{
Development and Testing of Chemistry Education Resources for a Mobile Phone
}

\author{
Tadayosi YOSHIMURA*, Yuusuke NAKAYAMA and Akinori UEJIMA \\ Fukui National College of Technology, Department of Chemistry and Biology Engineering \\ Geshi-cho, Sabae, Fukui 916-8507, Japan \\ *e-mail: tadayosi@fukui-nct.ac.jp
}

(Received: October 22, 2003; Accepted for publication: November 13, 2003; Published on Web: January 16, 2004)

\begin{abstract}
Despite their amazing profusion, mobile phones have not been a part of school education and there have been no reports on testing for their active use in this arena. We have thus developed chemistry resources via the Internet that allow mobile phones to be used as mobile computer terminals for educational purposes. Because mobile phone displays are extremely small, they are not suitable for viewing lengthy texts or large images over the Internet. In consideration of this limitation, we have developed chemistry resources that prioritize the greater convenience offered by mobile phones over desktop computers. We revised the "Physical Chemistry Experiment" preparation system, which was already available on the Internet, so that it could be accessed using a mobile telephone. The Physical Chemistry Experiment comprises 18 topics. Testing use of these resources began during student experiments in April, 2003, and this paper reports the results of our development efforts and the results of implementing these developments in the educational environment.
\end{abstract}

Keywords: Internet mobile telephone, Internet CAL system, Sentence display around 10 characters, Chemistry education system via the Internet

\section{Introduction}

In spite of the spread of mobile telephones, school education is a closed gateway for their use. There is seldom testing which positively carries out their utilization, and such reports are few [1-4]. A mobile telephone was used for education as an Internet mobile terminal. The chemistry education resources system via the Internet was developed as Internet CAL system. The display on a mobile telephone is extremely small for Web. It is not suitable for lengthy texts and large figures. The system was developed on the convenience of the portability against a desk computer. The chemistry education resources are "Physical Chemistry Experiment" [5] preparation system always open in Japanese via the Internet. It was revised to use a mobile telephone. The Physical Chemistry Experiment has been composed of 18 topics. It has been used for the testing of our student experiments since April, 2003. Then, the following are reported: research results on the development and education results in practical training.

\section{File preparation for mobile tele- phone Web System}

We cannot use a mobile telephone to utilize "Physical Chemistry Experiment" learning system under the open Internet. It is not suitable for mobile telephone display $(3 \mathrm{~cm} \times 4 \mathrm{~cm})$, because a desktop computer display is assumed. To begin with, it is divided into sentence information and image information within the document as object education resource. On the sentence, the lengthy texts were avoided, and a line expression of the sentence was chosen carefully in the single sentence. In the image information, the graphic data was reduced to display size (Figure 1). The party completes the short sentence for the description around 10 characters. An example is shown in Figure 2. The display with subscript and superscript on ion, chemical formula was made to be a line expression. The limited size of the mobile telephone does not become a fatal defect for the way of chemistry learning, even if two lines expression of chemical formula are not used. 


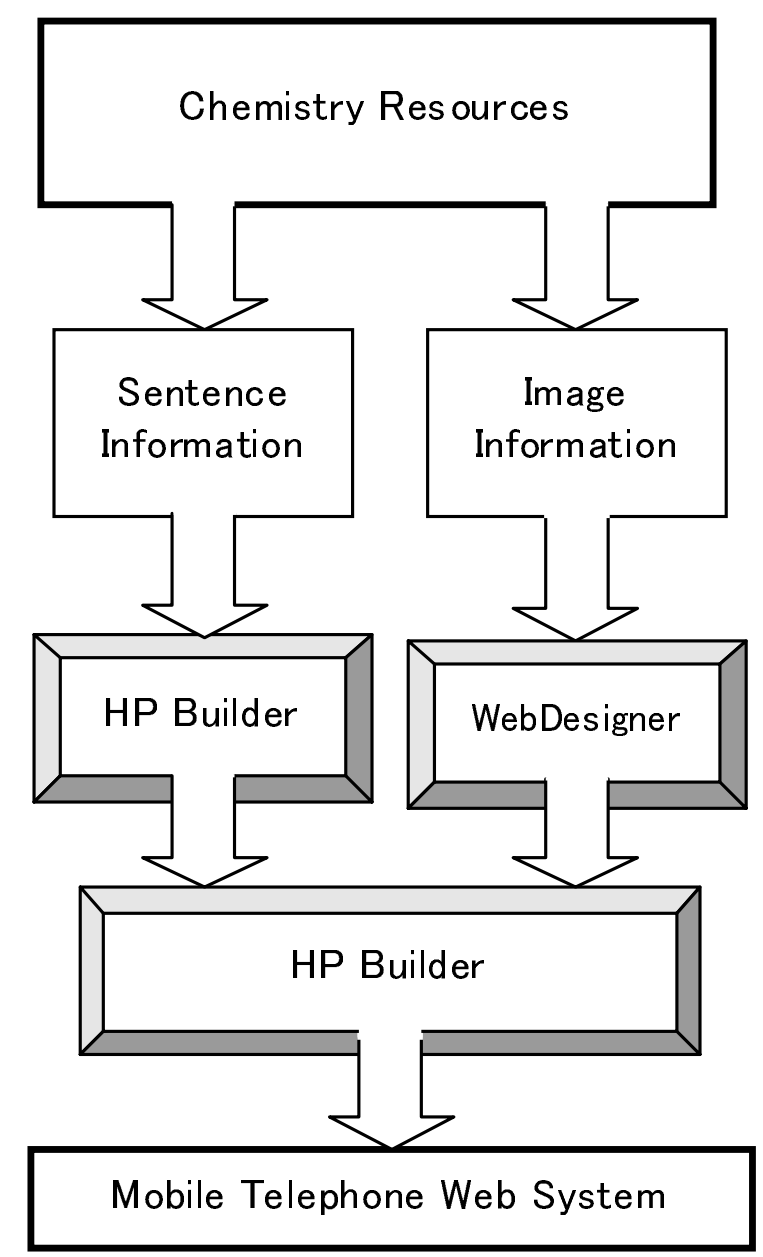

Figure 1. Preparation flow of the mobile telephone Web system.

Though the animation function could be prepared in the moving image, the graphic data was abandoned by the shortage of the hardware function for a mobile phone. The image data which photographed experimental equipment via digital camera were reduced using Adobe Photoshop to the display size. The equipment drawing processed the image using the Paint of the Windows OS attachment function. The color decrease was changed to 256 colors from the full color $(16,770,000$ colors $)$, and the level of the image capacity was optimized for mobile telephone by Optpix Web Designer.

Numeric data tables and graphs of the experimental results were processed using MS-Excel, and they were adjusted in size which was optimum on the display of mobile telephone. Verification of the data of the experimen- tal result is educationally necessary, because the topic of the chemistry education resource is practical training in student laboratory experiments. The network system was set for the data check under experiments and report generation without choosing any time and any place.

\section{Reduction processing of the im- age data}

Bitmap image was reduced at 9600 pixels $(100 \times 96)$ using Adobe Photoshop, and it was saved in a JPEG(jpg) type. The color of the file could be decreased from $16,770,000$ to 256 colors, using Optpix Web Designer. The reduction treatment was carried out in the size of image capacity of a few $\mathrm{KB}$, and the file was converted into a GIF type for Internet. An example case of reduction and processing is shown in Figure 3. Figure 3 shows the image "Optical Rotator" photographed by the digital camera.

Though the digital image in Figure 3 was $150 \mathrm{~KB}$, it decreased to $17 \mathrm{~KB}$ after being reduced. It was possible that the image capacity was made to decrease to about 1/10. By MS-Excel, the data measured by the experiment was converted to graph for the small size of a mobile telephone.

\section{Preparation of Web (HTML) file}

The source of the HTML file was made using the IBM HomePage Builder. The extra tag in mobile telephone Web was incorporated in the HTML file made by this builder. Using the Memo Pad of the Windows OS attachment function, deletion and correction of the unnecessary tags were carried out. Example of the object part of the correction is shown as follows;

$<$ !DOCTYPE HTML PUBLIC “-//W3C//DTD HTML 4.0 Transitional//EN">

$<$ META name="GENERATOR" content="IBM

HomePage Builder 2001 V5.0 for Windows">

Two lines of the above HTML tags were deleted,

because it was unnecessary for a mobile telephone.

$<\mathrm{P}$ align="center" $>\sim$ (sentence $) \sim</ \mathrm{P}>$

The line of the above tag was changed for the center setting as follows;

$<$ CENTER $>\sim($ sentence $) \sim</$ CENTER $>$

In addition, the tag of font size appointment that was automatically tagged was all deleted, because the appointment of the font size was unnecessary in Web for mobile telephone. 


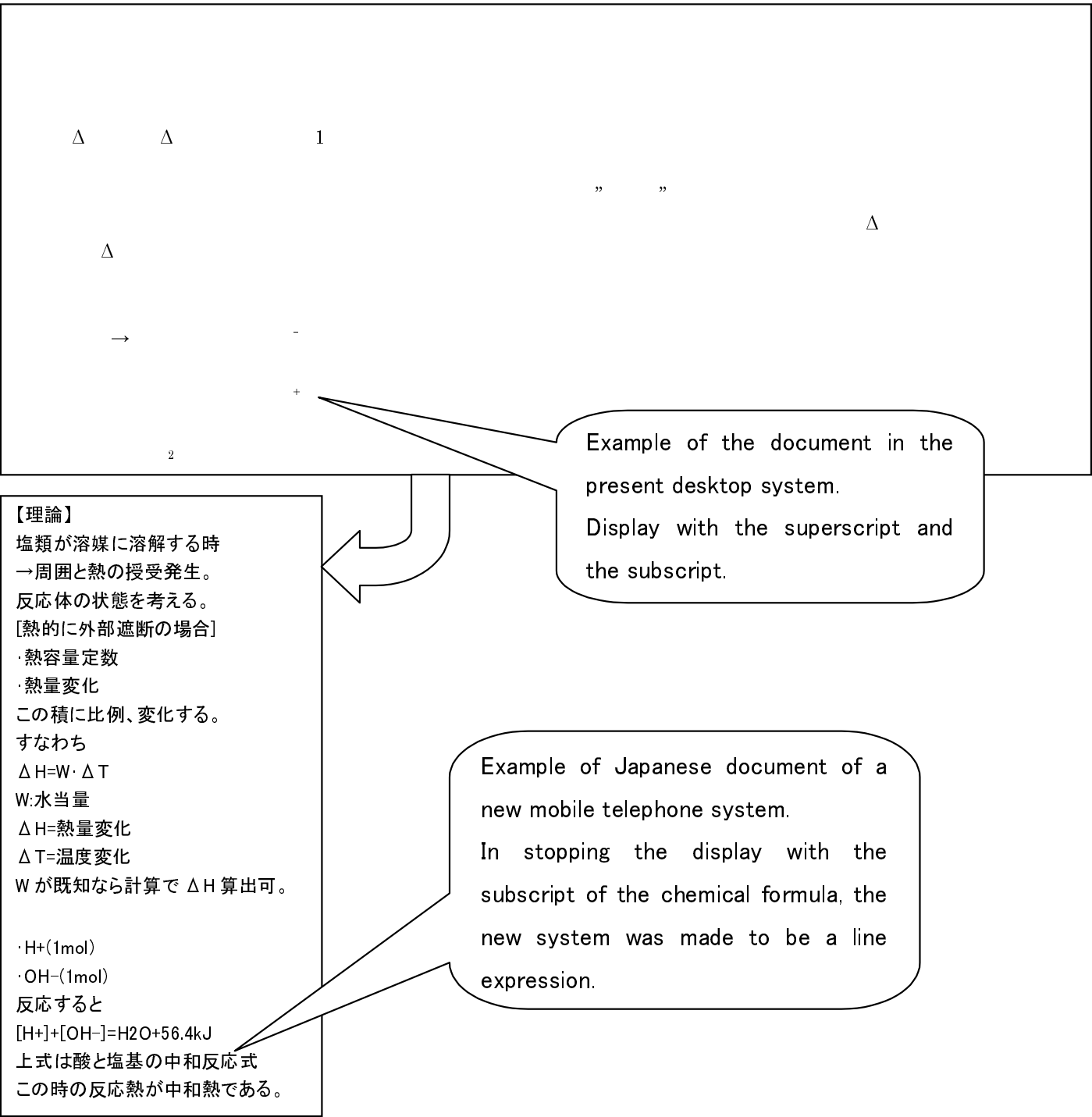

Figure 2. Example of the short sentence treatment from the sentence of the present Japanese system.

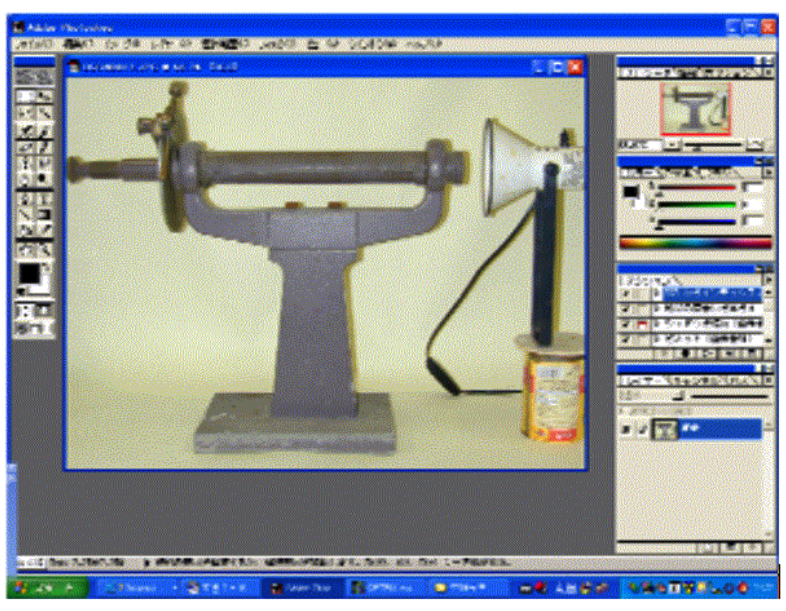

Figure 3. Reduction processing of the image by Photoshop.

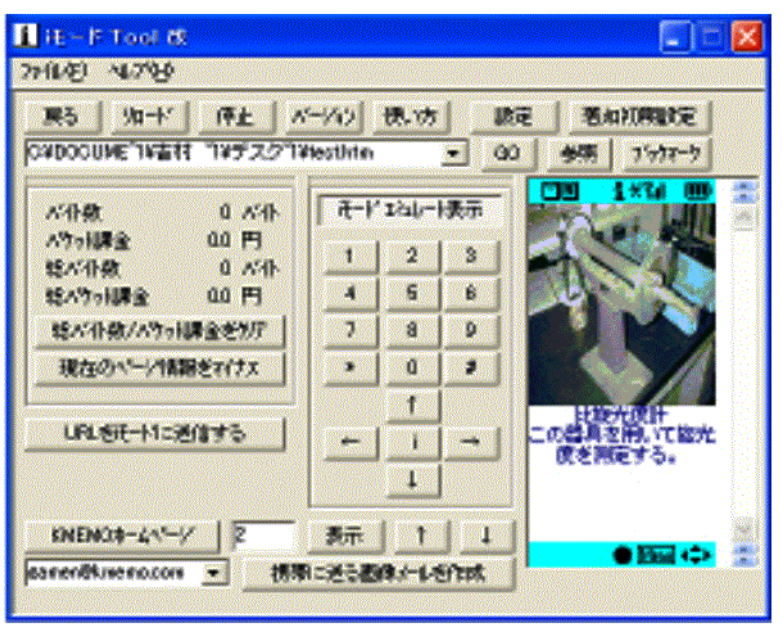

Figure 4. Simulation display using the browser "i-Mode Tool KAI". 


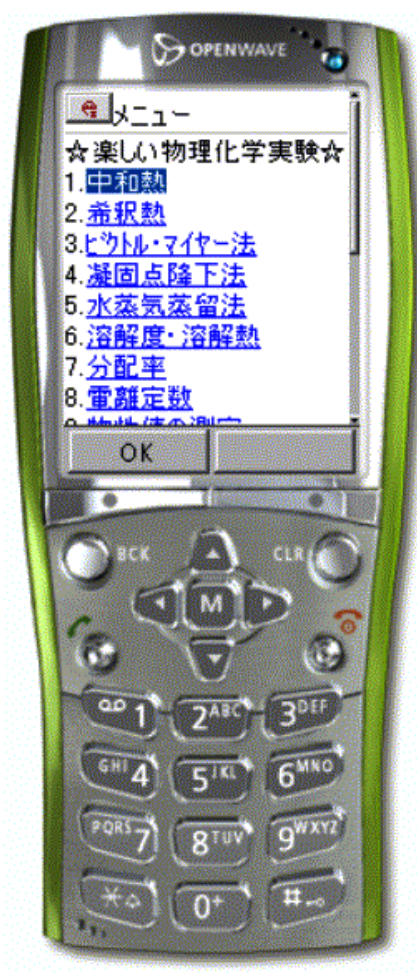

Figure 5. Menu file display simulated by using the browser "Openwave SDK Universal Edition 1.1"

\section{Questionnaire items \\ For the questions shown as follows, please evaluate the mobile telephone system in 5 stages. \\ S1. Is the mobile telephone system educational? \\ S2. Is there educational significance in a network arrangement by mobile telephone? \\ S3. Is it smoothly operated using the mobile telephone system?}

S4. This server has 18 topics. Is it useful to learn without choosing any place?

S5. Are mobile phones in network education necessary?

S6. Each chapter and section can be chosen from the menu. Is it useful?

S7. Do you learn independently by such mobile phone system?

Answer the above 7 items in the questionnaire.

Figure 6. Questionnaire items

the server. The download of the picture image was heavy, when it was accessed to this server by mobile telephone. Large reading load was applied even in the image file of about 10KB capacities which reduced the image size. In the present mobile phone, this file system was heavy for reading, when the document and the image were simultaneously displayed. The contrivance that takes in the image in button clicks, etc. seems to be suitable on the method for requiring the image in the present mobile phone system.

\section{Questionnaire in the testing of this system}

This system was used on testing for our students. Evaluation in 5 stages was received for questionnaire items (Figure 6) in order to examine the educational degree of the practicality. A good evaluation result is closer to 5, but a bad one is closer to 1 . For seven items of the questionnaire, Figure 7 shows the result after having tested 10 students. 


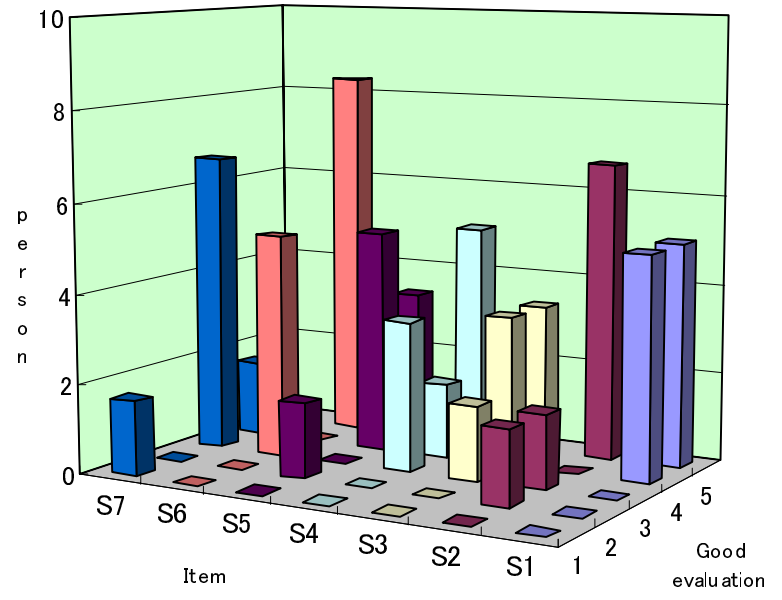

Figure 7. Good evaluation result for seven questionnaire items. Symbols $(\mathrm{S} 1, \cdots, \mathrm{S} 7)$ of questionnaire items are equal with Figure 6.

This system using a mobile telephone was judged as useful, and it received almost the passing mark. The comments described in the questionnaire are as follows: the punctuation mark is omitted; further short sentence is required; the clear indication of the important point by the experiment guideline; the visibility contrivance of the experimental equipment. In the negative evaluation, the cost of mobile telephone use is charged to the student. It is necessary that the use charge of the mobile telephone in the network become cheaper.

\section{Conclusion}

This system was produced as a graduation research (by Yuusuke Nakayama) in fiscal 2002. Testing of the use of these resources began during the student experiments in April, 2003. Thus, Internet utilization by opened desktop computer terminal is most useful for experiment practical training in our college. The utilization evaluation of the mobile phone system was fairly good for the student who used the part. Thus, the utilization (autonomy study of the student) of this system is practiced via a mobile telephone.

All students have a mobile telephone recently. The mobile telephone should be more used for Internet learning without choosing any time and any place. The mobile telephone is promoted for the self-study of the student in the network. The Internet education resources are also necessary because of the effective utilization of a mobile telephone.

\section{References}

[1] Ken-ichi Hayami, Kaoru Takahashi, Nahomi Fujiki, Masashi Oida, Introduction of the WWW page preparation for mobile telephone to practical training, Journal of JSEE, 50(2), 31-37 (2002).

[2] Yoshio Honma, Introduction of chemistry suggestion "i-Chemistry" in the IT age, Chem. Software, 23(2), 96 (2001).

http://www.nicol.ac.jp//honma/report2001/i-chem .html

[3] Yoshio Honma, Web page preparation and utilization by mobile telephone for the chemical education, The 79th spring annual meeting proceeding I, Chemical Soc. of Japan, 547 (1999).

[4] Yoshio Honma, Present Situation and Practices of Cellular Phone Use in Educational Field, $J$. Information Science and Technology Association, 52(12), 615-620 (2002).

[5] Noboru Ashida, Yoshihiro Aoyama, Tadayosi Yoshimura, Brian T. Newbold, Development and the Use of Chemical Teaching Video Materials by Internet Browser, J. Chemical Software, 4, 51-56 (1998).

[6] "i-Mode Tool KAI" is a freeware made by Seiichi Nishimura.

[7] "Openwave SDK Universal Edition 1.1" is a freeware made by Open Systems Inc. 


\title{
携帯電話を 利用し たインターネット 化学教材の開発と 活用
}

\author{
吉村忠与志*, 中山 裕介, 上嶋 晃智 \\ 福井工業高等専門学校＼cjkstart物質工学科, $\bar{T}$ 916-8507 鯖江市下司町 16-1 \\ *e-mail: tadayosi@fukui-nct.ac.jp
}

最近のすべての学生は携帯電話を携行し、インターネットに接続していろいろな情報を獲得してい る。しかし、学校教育においては、教育上有害物質として教育利用を怠っている。光して、積極的な 教育利用の報告もない。弚のような中で、我々は携帯電話のモバイル性を生かして、化学実験の事前・ 事後学習のための「物理化学実験 CAL システム」の携帯電話向けの改訂を検討した。従来のインター ネット CAL システムはデスクトップコンピュータのディスプレイを想定したものであり、携帯電話の 小さなディスプレイには適合しない。乥こで、携帯電話向けの改訂に伴う諸問題を提起し、作製した 携帯電話向け化学教材システムの開発と活用に関する成果を得た。

キーワード : インターネット携帯電話, インターネット CAL システム, 10 文字列による文章表記, イ ンターネットによる化学教材システム 